\title{
Life Cycle Performance of Hydrogen Production via Agro-Industrial Residue Gasification-A Small Scale Power Plant Study
}

\author{
Sara Rajabi Hamedani ${ }^{1}$, Mauro Villarini ${ }^{2, *(1)}$, Andrea Colantoni ${ }^{2}{ }^{(\mathbb{B})}$, Michele Moretti $^{3}(\mathbb{D})$ and \\ Enrico Bocci ${ }^{4}$ \\ 1 Department of Astronautics, Electrical and Energy Engineering, Sapienza University, 00184 Rome, Italy; \\ sara.rajabi@uniroma1.it \\ 2 Department of Agricultural and Forestry Sciences, Tuscia University of Viterbo-Via San Camillo de Lellis, \\ snc, 01100 Viterbo, Italy; colantoni@unitus.it \\ 3 Research Group of Environmental Economics, Center for Environmental Sciences, Hasselt University, \\ Agoralaan—Building D, 3590 Diepenbeek, Belgium; michele.moretti@uhasselt.be \\ 4 Department of Innovation and Information Engineering, Marconi University, 00193 Rome, Italy; \\ e.bocci@unimarconi.it \\ * Correspondence: mauro.villarini@unitus.it; Tel.: +39-340-226-6196
}

Received: 28 January 2018; Accepted: 13 March 2018; Published: 16 March 2018

\begin{abstract}
This study evaluates the environmental profile of a real biomass-based hydrogen production small-scale $\left(1 \mathrm{MW}_{\text {th }}\right)$ system composed of catalytic candle indirectly heated steam gasifier coupled with zinc oxide $(\mathrm{ZnO})$ guard bed, water gas shift (WGS) and pressure swing absorber (PSA) reactors. Environmental performance from cradle-to-gate was investigated by life cycle assessment (LCA) methodology. Biomass production shows high influence over all impact categories. In the syngas production process, the main impacts observed are global warming potential (GWP) and acidification potential (AP). Flue gas emission from gasifier burner has the largest proportion of total GWP. The residual off gas use in internal combustion engine (ICE) leads to important environmental savings for all categories. Hydrogen renewability score is computed as $90 \%$ due to over $100 \%$ decline in non-renewable energy demand. Sensitivity analysis shows that increase in hydrogen production efficiency does not necessarily result in decrease in environmental impacts. In addition, economic allocation of environmental charges increases all impact categories, especially AP and photochemical oxidation (POFP).
\end{abstract}

Keywords: hydrogen production; biomass gasification; life cycle assessment; environmental impact

\section{Introduction}

Growing concerns about climate change, rising costs of fossil fuel, and the geopolitical uncertainty associated with an uninterrupted energy supply have motivated individuals, organizations and nations to look for substitutes that are clean and renewable [1,2]. Hydrogen $\left(\mathrm{H}_{2}\right)$ is, currently, considered as one of the leading candidates in the search alternatives to fossil fuels (FF) [3]. Nevertheless, $\mathrm{H}_{2}$ is only an energy carrier like electricity and not a primary energy source. It can be produced from a wide variety of energy sources, such as natural gas, coal, biomass, solar (thermal and photovoltaic), etc. [4] and act as a unique energy hub providing low or zero emission in energy use to all energy consuming sectors [5]. However, the environmental performance of hydrogen-production systems highly depends on the type of primary energy and conversion technology used [6]. Among several renewable energy sources, bio-hydrogen is gaining a lot of attraction because of its conversion efficiency with less pollutant generation [7]. In particular, hydrogen production through lignocellulosic biomass residues gasification 
is a promising pathway in terms of global warming impacts and energy security [8-10]. However, although lignocellulosic biomass is a renewable resource, its use does not guarantee an appropriate environmental performance [11] and, even under strategies of using agriculture and forestry residues to avoid emissions from direct and indirect land use change, the feedstock use can potentially cause negative environmental impacts [12]. Therefore, it is requisite to analyze entire biomass to hydrogen production process considering the impacts from the cultivation to the conversion plant.

LCA is a well-established methodology to evaluate the environmental impacts of a product over its life cycle. It is often used to determine the greenhouse gas footprint and minimum selling price in several kinds of processes and in particular regarding biomasses [13]. This is achieved by: (i) gathering all relevant inputs and outputs of the considered system; (ii) evaluating the potential environmental impacts related to these inputs and outputs; and (iii) interpreting the results obtained in the impact assessment phase [14]. Hence, LCA is a viable tool to identify environmental hotspots and find approaches that enhance environmental results related to the products $[15,16]$. The LCA application to energy is becoming increasingly important for evaluating which technology is more affordable and more sustainable [17]. LCA often demonstrated the benefits of replacement of oil with bioenergy systems [18] not only for energy but also for refinery scopes [19]. Despite the potential role of LCA in sustainable development of energy systems [20], few LCA studies have been carried out on $\mathrm{H}_{2}$ production from biomass $[8,9,21,22]$. In these papers, agricultural and forestry waste that feed oxygen/steam fixed or circulating fluidized bed coupled with tar cracker/reformer/scrubber, sulfur removal systems, steam reformer and water gas shift reactors have been assessed. Kalinci et al. [9] evaluated two different large scale gasification systems, circulating fluidized bed and fixed bed gasifiers coupled with tar reformer, water gas shift (HTS (High Temperature Shift), MTS (Medium Temperature Shift), and LTS (Low Temperature Shift)) and PSA reactors. In this study, impacts were just evaluated in term of $\mathrm{kg} \mathrm{CO}_{2}$. Moreno and Dufour [21] investigated environmental efficiency of a $131 \mathrm{MW}_{\text {th }}$ power plant that applied a fixed bed gasifier with steam reformer, WGS and PSA. Susmozas et al. [8] assessed biomass gasification via circulating fluidized bed gasifier and SMR technology for hydrogen production in a medium size power plant. $\mathrm{ZnO}$ reactor and steam reformer were not included. Finally, Suwatthikul et al. [22], after the model implementation, by means of ASPEN Plus, a simulation software for chemical process, of a steam gasification system and its validation, developed a LCA comparing conventional gasification and energy self-sufficient gasification in terms of GWP and marine aquatic ecotoxicity.

Since biomass resources are typical of a distributed nature and are limited by low energy density, perishability and complexity of the supply chain, distributed power plants offer significantly better energy security and possibility to exploit the full potential than the equivalent centralized plant $[23,24]$. To sustain development of these distributed units, reliable, high efficient and low environmental impact small scale power plants have to be developed [24]. Thus, it is important to conduct a LCA of hydrogen production at small scale systems. Previous literature regarding this specific topic is missing and, therefore, the contribution of the present study is relevant because it deals with LCA of hydrogen production via small scale biomass plant realized during four-year project of UNIfHY (UNIque gasifier for HYdrogen production) [25]. In this case study, almond shell, which represents agro-industrial residue, is used as feedstock, and a catalytic candle indirectly heated steam gasifier coupled with zinc oxide (ZnO) guard bed, water gas shift (WGS) and pressure swing absorber (PSA) reactors is considered as conversion technology. Almond shell has been chosen because it has the most suitable characteristics to this thermochemical process, as explained by Bocci et al. [24]. The chemical characterization of any feedstock to be used in a gasification process is an important step for qualifying the process itself in terms of conversion efficiency (mass and energy) and presence of potential poisoning elements. In this paper, almond shells have been selected as representative of agro industrial residue because, as a food industry derived biomass source, they are largely available, have a limited cost of supply, do not have potential poisoning elements and have already been tested in the UNIfHY project [25]. 
The article is organized as follows: after the Introduction, Section 2 describes the methodology used; Section 3 reports a description of the conceptual organization of the gasification system within the model; Sections 4 and 5, respectively, present and discuss the main results of the work; and Section 6 reports the conclusions.

\section{Methodology}

\subsection{The Life Cycle Assessment}

LCA is a methodology for the comprehensive evaluation of the impact that a product (good or service) has on the environment throughout its life cycle [14]. This method presents a holistic approach for a comprehensive environmental assessment, following a standardized method which guarantees reproducibility of results $[14,26]$.

\subsubsection{Goal and Scope Definition}

The environmental impacts and energy requirements of the whole process aimed at hydrogen production from the almond shell by means of gasification process and the subsequent use for electricity have been determined. In addition, environmental hotspots were identified to reduce the impact and improve the environmental and energy profiles. StimaPro 8.1 software, developed by PRé Consultants, was used for the environmental evaluation of the process.

\subsubsection{Functional Unit and System Boundaries}

The functional unit (FU) expresses the function of the system in quantitative terms and provides the reference to which all the inputs and outputs of the product system are calculated [14]. The functional unit selected for this assessment was the production of $1 \mathrm{MJ}$ of hydrogen (purity: 99.99\%).

A cradle-to-gate LCA has been performed including feedstock production, gasification, $\mathrm{H}_{2}$ purification and electricity generation from off-gas.

\subsubsection{Inventory Data Acquisition}

The most effort-consuming step in the execution of LCA studies is the collection of inventory data to build the Life Cycle Inventory (LCI). High quality data (input and output) are essential for a reliable evaluation [27].

Inventory data for the bioenergy production plant are collected from foreground data of a pilot plant and form questionnaire filled out by designer, producer and operators of the equipment and gasifier plant. In feedstock production phase, on farm emissions derived from fertilizer application have also been modeled following the IPCC (Intergovernmental Panel on Climate Change) guidelines [28]. Temporary storage of carbon in tree biomass, and carbon storage in orchard soils, is accounted for based on net annual changes in carbon stored or emitted. The average soil carbon accumulation in almond orchards was estimated as $624 \mathrm{~kg}$ of carbon ha $\mathrm{ha}^{-1} \mathrm{year}^{-1}$. More detailed information concerning these calculations can be found in [29]. Emissions from fuel combustion in both bioenergy plant and agricultural machinery have been calculated according to Tier 1 method described in IPCC guidelines. The fuel consumption does not include the extraction stage. The inventory involves the distribution of fuel to the final consumer including all necessary transports. In the off-gas management subsystem presented in the following paragraph, the derived emissions from CHP were calculated with the emission limits reported by [30].

\subsubsection{Impact Assessment}

According to some criteria defined for selecting the impact assessment methods, such as the scientific robustness, which considers the level of uncertainty, development that occurs over time, their application in LCA practice and the European environmental policy goals, the midpoint CML method is chosen to assess hydrogen production system (Fuel cell and Hydrogen-Joint Undertaking 2011). 
In line with [31-33], four midpoint categories were taking into account: acidification potential (AP), eutrophication potential (EP), global warming potential (GWP) and photochemical oxidation potential (POFP). The cumulative (non-renewable) fossil and nuclear energy demand (CED) of the whole life cycle was also quantified [34].

\subsection{Hydrogen Renewability}

The concept of renewability has firstly been introduced by Neelis et al. [35] and, as an indicator, it can assist decision makers to choose fuel with superior renewability character. According to cumulative energy demand (CED) method, renewable and non-renewable energy involved in whole life cycle can be counted. The index represented for this cycle is shown in Equation (1), [35]:

$$
\text { Hydrogen renewability }[\%]=\frac{\text { renewable energy input }}{(\text { renewable energy }+ \text { nonrenewable energy inputs })}
$$

\subsection{Sensitivity Analysis}

In addition, sensitivity analysis has been performed to assess the influence of change in hydrogen production efficiency and environmental charge allocation on the model results. Among the factors that affect hydrogen production, the steam to biomass ratio (S/B) has been chosen [36,37]. Therefore, study results have been compared with those considering S/B equal to 1 and 1.5, respectively. Experimental conditions for these different ratios are found in [38]. Alternatively, an economic allocation between hydrogen and electricity produced in the bio-energy plant was assumed. According to [39,40], allocation percentages for hydrogen and electricity in economic basis were $96 \%$ and $4 \%$, respectively.

\section{Description and Model of the Gasification System}

The present system is based on a $1 \mathrm{MW}_{\text {th }}$ innovative gasification system [41-43]. Figure 1 shows the CHEMCAD, a simulation software for chemical process, flowsheet of the system with the indirectly heated gasifier here considered. To realize the $1 \mathrm{MW}_{\text {th }}$ system with Steam-Oxygen gasifier, the depicted plant in Figure 2 is used.

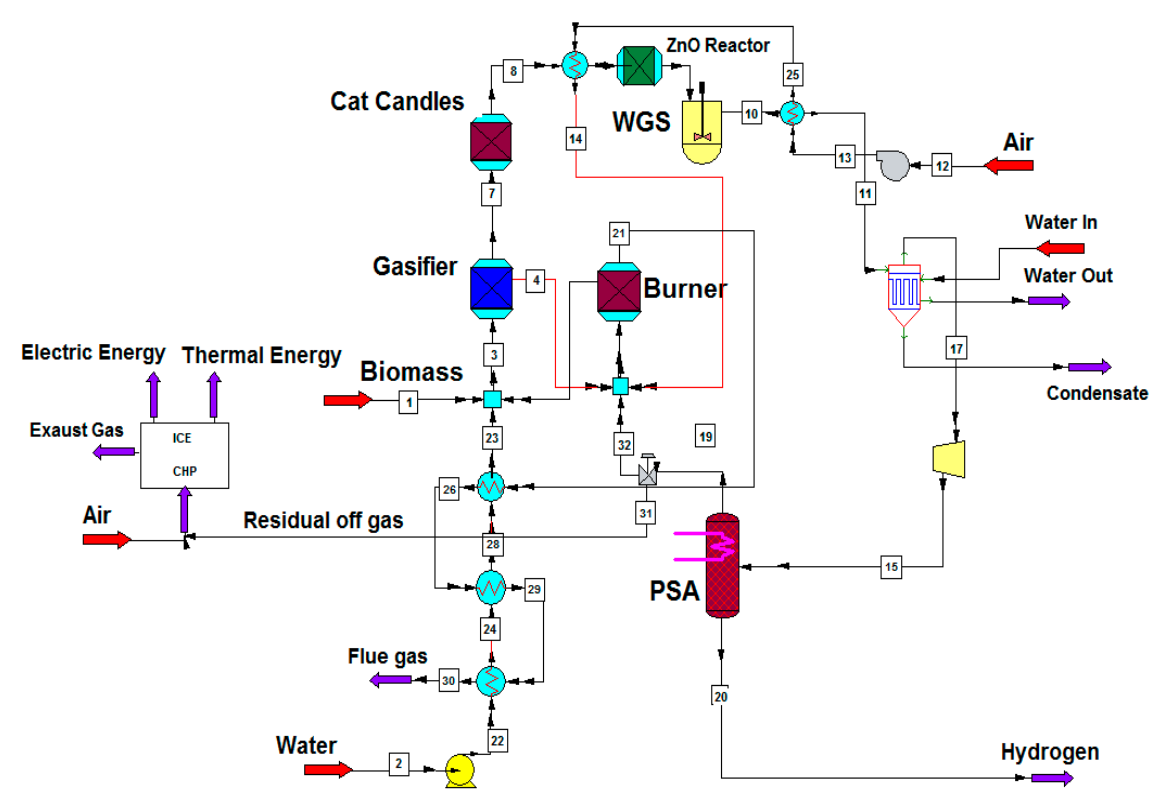

Figure 1. Flow sheet of the plant evaluated in this study. 


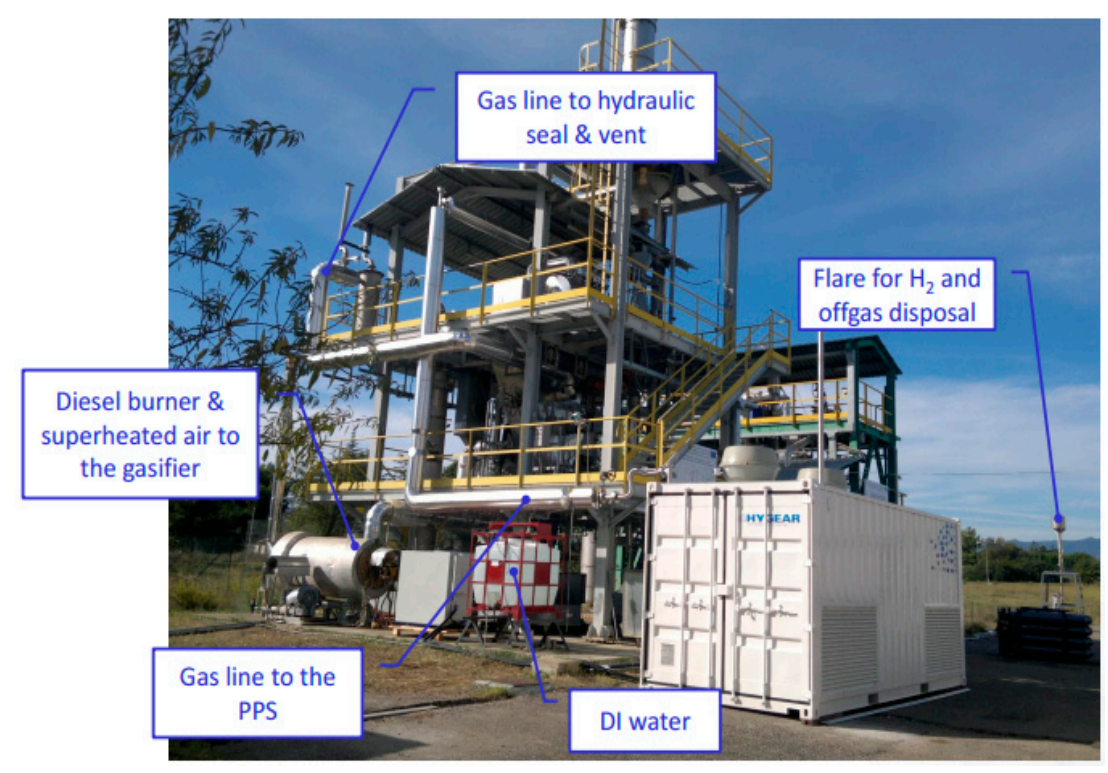

Figure 2. A picture of the plant.

The system is divided into four subsystems. First is the Biomass production (SS1). The bioenergy plant operation has been divided into two main stages: from biomass to syngas representing the syngas production stage (SS2) and from syngas to hydrogen representing the syngas conversion stage (SS3). All inputs and outputs demanded for the plant operations are included to consider the related environmental burdens. The last subsystem is composed of the off-gas management (SS4). Figure 3 illustrates the system boundaries and the considered processes.

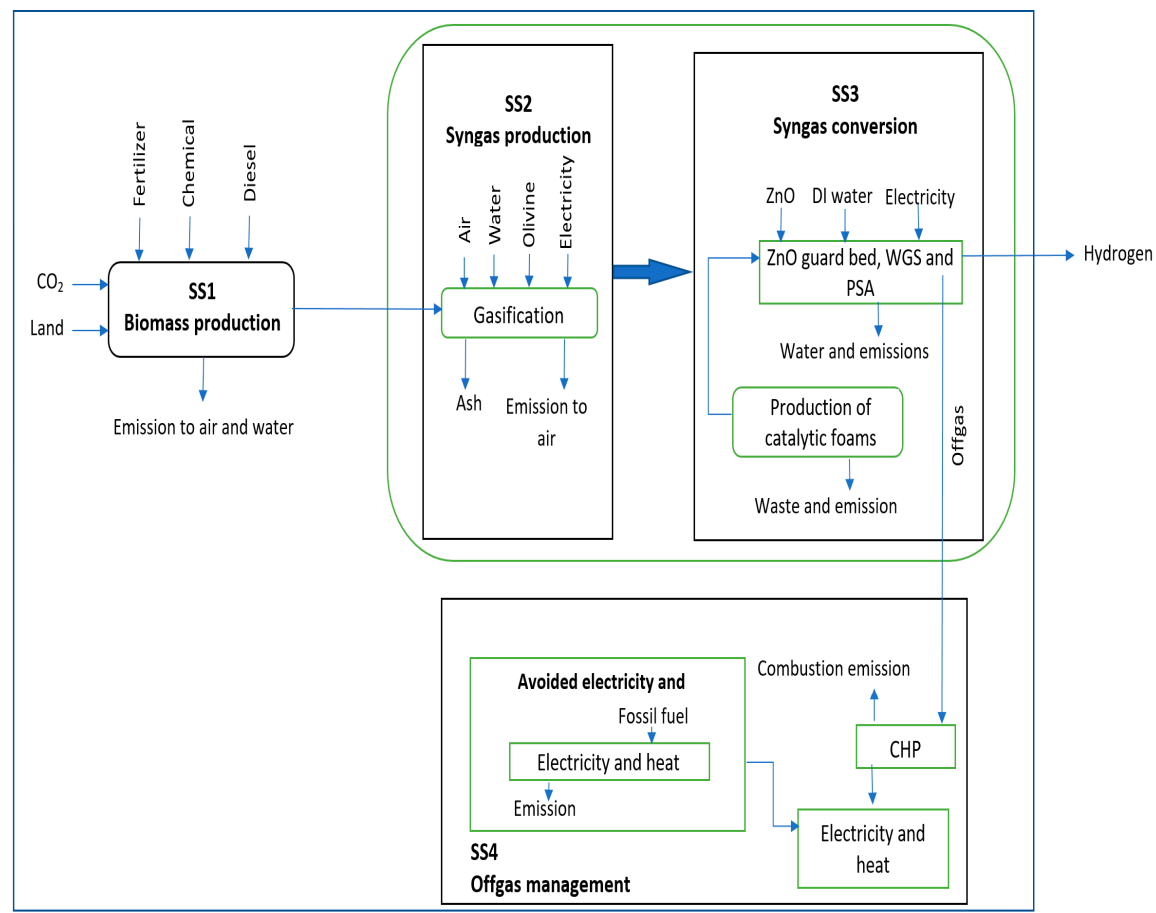

Figure 3. Life cycle boundaries for hydrogen production system. 


\subsection{Subsystem 1: Biomass Production}

In Subsystem 1, all the biomass production processes were considered, comprising main crop planting, fuels consumed by agricultural machinery, requirements of fertilizer, pesticides and water for irrigation, transportation, fuel consumed in factory and biomass collection [29,44,45]. The global inventory data for this subsystem are reported in Table 1. Since waste production is not the goal of farming, it is required to designate all outputs (main products and waste) of cultivation and adapt allocation method to account only for the environmental burdens allocated to waste [21,27]. In this study, environmental charges of cultivation stage are allocated using market prices ( $1 \%$ of charge associated to waste).

Table 1. Global inventory data (per $1 \mathrm{MJ}_{\mathrm{H} 2}$ ) for Subsystem 1.

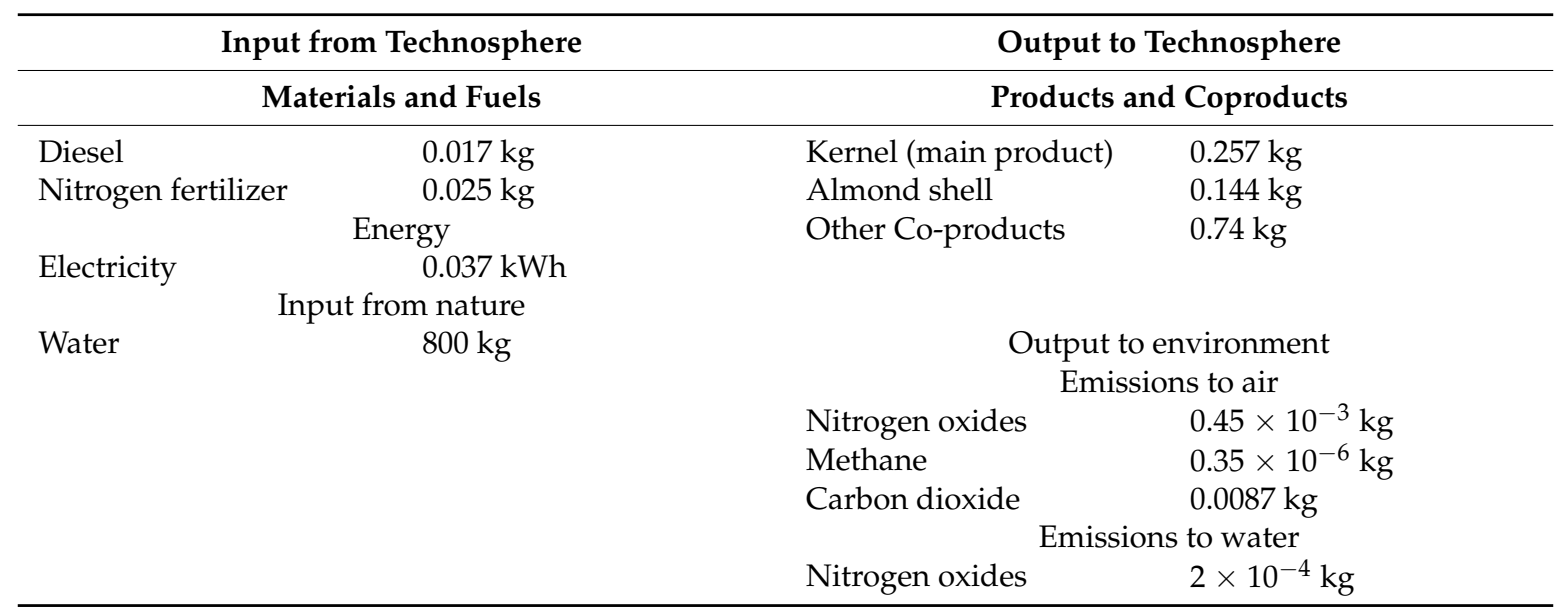

\subsection{Subsystem 2: Syngas Production}

The main operating conditions of the entire power plant are listed in Table 2 [38]. In addition, almond shell characterization and syngas composition are shown in Tables 3 and 4, respectively.

Table 2. Operating conditions of the gasifier.

\begin{tabular}{ll}
\hline Parameters $($ Unit) & Value \\
\hline Power $\left(\mathrm{kW}_{\text {th }}\right)$ & 1000 \\
Biomass feeding rate $(\mathrm{kg} / \mathrm{h})$ & 200 \\
Steam feeding rate $(\mathrm{kg} / \mathrm{h})$ & 100 \\
Electricity consumption $(\mathrm{kW})$ & \\
Start up & 4 \\
water pump & 0.61 \\
Air blower & 13 \\
Syngas blower & 3 \\
Syngas Compressor & 36 \\
Gasification T $\left({ }^{\circ} \mathrm{C}\right)$ & 850 \\
S/B & 0.5 \\
Combustor T $\left({ }^{\circ} \mathrm{C}\right)$ & 950 \\
Olivine between combustor/gasifier $(\mathrm{kg} / \mathrm{h})$ & 1000 \\
\hline
\end{tabular}

Table 3. Almond shell characterization [46].

\begin{tabular}{ccccccccccc}
\hline $\begin{array}{c}\text { Bulk Density } \\
\left(\mathbf{k g} / \mathbf{m}^{\mathbf{3}}\right)\end{array}$ & $\begin{array}{c}\text { Humidity } \\
(\% \mathrm{wt})\end{array}$ & $\begin{array}{c}\text { Ash } \\
(\% \mathbf{w t})\end{array}$ & $\begin{array}{c}\text { Volatile Matter } \\
(\% \mathbf{w t})\end{array}$ & $\begin{array}{c}\text { Fixed Carbon } \\
(\% \mathbf{w t})\end{array}$ & $\mathbf{C}(\%)$ & $\mathbf{H}(\%)$ & $\mathbf{N}(\%)$ & $\mathbf{O}(\%)$ & $\mathrm{CI}(\%)$ & $\mathbf{S ~ ( \% )}$ \\
\hline 450 & 12 & 1.2 & 80.6 & 18.2 & 47.9 & 6.3 & 0.32 & 44.27 & 0.012 & 0.015 \\
\hline
\end{tabular}


Table 4. Syngas composition.

\begin{tabular}{ll}
\hline Compositions (Unit) & Value \\
\hline Gas yield $\left(\mathrm{Nm}^{3}{ }_{\text {dry }} / \mathrm{kg}_{\text {bio,daf }}\right)$ & 1.45 \\
$\mathrm{H}_{2}\left(\%_{\text {dry }}\right)$ & 44 \\
$\mathrm{CH}_{4}\left(\%_{\text {dry }}\right)$ & 10 \\
$\mathrm{CO}\left(\%_{\text {dry }}\right)$ & 28 \\
$\mathrm{CO}(\%$ dry $)$ & 18 \\
$\mathrm{H}_{2} \mathrm{O}(\%$ wet $)$ & 16 \\
$\mathrm{C}_{6} \mathrm{H}_{6}\left(\mathrm{~g} / \mathrm{Nm}^{3}\right.$ dry $)$ & 4.11 \\
$\mathrm{C}_{7} \mathrm{H}_{8}\left(\mathrm{~g} / \mathrm{Nm}^{3}{ }_{\text {dry }}\right)$ & 0.68 \\
$\mathrm{C}_{10} \mathrm{H}_{8}\left(\mathrm{~g} / \mathrm{Nm}^{3}{ }_{\text {dry }}\right)$ & 0.68 \\
$\mathrm{MJ} / \mathrm{Nm}^{3}$ dry & 11.4 \\
\hline
\end{tabular}

Syngas production stage involves the gasification process. Gasification is performed in a $1 \mathrm{MW}_{\text {th }}$ Indirectly heated Bubbling Fluidized Bed gasifier (IBFB), working under mentioned conditions in Table 2 for 7000 operating hours (even if during the project only $120 \mathrm{~h}$ of pure hydrogen production has been achieved). Indirectly heated bubbling fluidized bed with tar reforming inside the gasifier was chosen in this study since this configuration provides a synthesis gas with higher hydrogen content than fluidized and fixed bed gasifiers [6,36,41,47-49]. The $1 \mathrm{MW}_{\text {th }}$ gasifier built and experimented in the research project is an oxygen bubbling fluidized bed gasifier. Thus, we considered the same technology running in indirectly heated configuration.

First, tar and methane are treated and the cleaning process of synthesis gas from particles is carried out by 60 Catalytic Filter Candles (CFC) allocated in the gasifier freeboard. This is an innovative method adapted and tested during the two European research projects called UNIQUE [50] and UNIfHY [25]. In the gasification process, both electricity and heat are requisite. The electricity consumed in the syngas compressor and in the air blower is taken directly from the Italian national grid. Thermal energy is required to preheat the air, heat the water, and generate and overheat the steam, and is provided by syngas and flue gas cooling. Owing to the indirectly heated configuration, hot bed material (olivine) from the combustor is circulated back to the gasifier supplying the thermal power needed for the gasification reactions. Carbon dioxide emissions from flue gas have been considered.

\subsection{Subsystem 3: Syngas Conversion}

In the syngas conversion stage, the produced syngas has been used in a portable purification station (PPS), which generates the $\mathrm{H}_{2}$. This unit combines a $\mathrm{ZnO}$ reactor (to remove the sulfur compounds within syngas), a WGS reactor (to convert $\mathrm{CO}$ into further $\mathrm{H}_{2}$ ) and a PSA membrane reactor (to separate $\mathrm{H}_{2}$ from the other syngas components). Since atmospheric pressure gasification is more suitable for small-scale applications, the conventional WGS that operates at high pressure has been substitute with ceramic foams catalytic WGS operating at atmospheric pressure. The use of a ceramic foam with a wide catalytic surface area impregnated with catalyst eliminates the need to operate at high pressure for high conversion efficiency [36].

The $\mathrm{ZnO}$ data have been considered but this unit is not present in the flowsheet because the trace elements have not been considered in the simulation. The heat from the heat exchangers in PPS is recovered to meet low temperature thermal need.

All inputs and outputs needed for the hydrogen production unit (PPS), such as electricity, ZnO, de-ionized water and WGS Cu foams, are included. Additionally, the derived emissions from burning off-gas (such as nitrogen oxides, carbon dioxide, and sulfur dioxide) were considered. Construction of gasifier plant with 20-year life time has also been considered within the subsystem boundaries. The details of catalysts production are extracted from a questionnaire filled out by the University of Strasburg, a partner of UNIfHY project. The materials and energy inputs required for the catalysts production to be used in a $1 \mathrm{MW}_{\text {th }}$ power plant are presented in Table 5. 
Table 5. Material and energy employed for catalysts production.

\begin{tabular}{ll}
\hline Parameters (Unit) & Value \\
\hline Number & 20 \\
Size $(\mathrm{cm})$ & D: 70 \\
Material and Energy & $\mathrm{H}: 10$ \\
Water $(\mathrm{kg})$ & \\
Cerium nitrate $(\mathrm{kg})$ & 800 \\
Heat $(\mathrm{MJ})$ & 367 \\
Lifetime (year) & 12,000 \\
Emission to water & 3 \\
Cerium nitrate solution (L) & 500 \\
Copper nitrate solution (L) & 500 \\
Emission to air (kg) & \\
$\mathrm{NO}_{\mathrm{x}}(\mathrm{kg})$ & 6 \\
\hline
\end{tabular}

During the 20-year lifetime of power plant, the catalysts with three-year lifetime need to be replaced seven times. To integrate this production phase into the model, the energy and materials required for these catalysts (Table 5) have been multiplied by seven and divided by the total energy output produced during 20 years.

The main inventory data for hydrogen production via almond shell gasification are shown in Table 6.

Table 6. Main inventory data for hydrogen production via almond shell gasification per FU.

\begin{tabular}{|c|c|c|c|}
\hline \multicolumn{2}{|c|}{ Input from Technosphere } & \multicolumn{2}{|c|}{ Output to Technosphere } \\
\hline \multicolumn{2}{|c|}{ Materials and fuels } & \multicolumn{2}{|c|}{ Products and coproducts } \\
\hline Almond shell (SS1) & $0.144 \mathrm{~kg}$ & Hydrogen & $1 \mathrm{MJ}$ \\
\hline Diesel (SS2) & $3.55 \times 10^{-5} \mathrm{~kg}$ & & \\
\hline Water (SS2) & $0.144 \mathrm{~kg}$ & \multirow{2}{*}{\multicolumn{2}{|c|}{ Avoided product }} \\
\hline De-ionized water (SS3) & $0.128 \mathrm{~kg}$ & & \\
\hline Zinc oxide (SS3) & $1.3 \times 10^{-4} \mathrm{~kg}$ & \multirow[t]{3}{*}{ Electricity } & \multirow[t]{3}{*}{$0.26 \mathrm{kWh}$} \\
\hline $\mathrm{Cu}$ foam (SS3) & $3 \times 10^{-7} \mathrm{P}$ & & \\
\hline Energy & & & \\
\hline Electricity (SS2) & $0.014 \mathrm{kWh}$ & \multirow{2}{*}{\multicolumn{2}{|c|}{ Emissions to air }} \\
\hline Electricity (SS3) & $0.027 \mathrm{kWh}$ & & \\
\hline \multirow{2}{*}{\multicolumn{2}{|c|}{ Input from nature }} & Nitrogen oxide (SS2) & $1 \times 10^{-9} \mathrm{~kg}$ \\
\hline & & Methane (SS2) & $1.7 \times 10^{-8} \mathrm{~kg}$ \\
\hline \multirow[t]{11}{*}{ Olivine (SS2) } & $0.00027 \mathrm{~kg}$ & Carbon dioxide (SS2) & $0.16 \mathrm{~kg}$ \\
\hline & & Water (SS2) & $0.15 \mathrm{~kg}$ \\
\hline & & Sulfur dioxide (SS4) & $2 \times 10^{-6} \mathrm{~kg}$ \\
\hline & & Nitrogen oxide (SS4) & $2.5 \times 10^{-5} \mathrm{~kg}$ \\
\hline & & \multicolumn{2}{|c|}{ Emission to water } \\
\hline & & Wastewater (SS3) & $0.05 \mathrm{~kg}$ \\
\hline & & \multicolumn{2}{|c|}{ Solid waste flows } \\
\hline & & Ash (SS2) & $1.6 \times 10^{-3} \mathrm{~kg}$ \\
\hline & & Olivine (SS2) & $2.7 \times 10^{-4} \mathrm{~kg}$ \\
\hline & & Insulation (SS2) & $5.5 \times 10^{-7} \mathrm{~kg}$ \\
\hline & & Hydrogen Sulfide (SS3) & $5 \times 10^{-5} \mathrm{~kg}$ \\
\hline
\end{tabular}

\subsection{Subsystem 4: Off-Gas Management}

In the syngas conversion process, off-gas is co-produced from PSA and is mainly used in the burner (syngas production process). This subsystem involves the use of the residual off gas into a conventional Combined Heat and Power system (CHP, via an Internal Combustion Engine, ICE). Under the conditions mentioned in Table 2, with respect to the total energy output: the energy content 
of residual off-gas represents $12 \%$; the $\mathrm{H}_{2}$ represents $43 \%$; and the thermal energy losses are $45 \%$ (8\% in flue gas and another $37 \%$ mainly due to the heat of the cooling water and condensate) (Figure 1).

According to previous energy study of the authors [38] and Fremaux et al. [37], it is inferred that the residual off-gas decreases with higher S/B ratio (e.g., with S/B greater than 1.5-2, depending on the PSA efficiency, the off-gas is completely used in the burner). In particular, the global efficiency is limited by the thermal losses and by the PSA compressor consumption. The hydrogen efficiency is limited by the PSA efficiency and by the absence of a methane reformer. Thus, to increase the hydrogen efficiency, high temperature hydrogen membrane separation that works at low pressure (as Palladium membranes) including methane reforming are considered but, up to now, are still in a development phase. Indeed, the hydrogen efficiency is about 38\%, while the global efficiency (considering hydrogen, residual off gas and the useful heat) is about $70 \%$.

The production of off-gas, under the fixed gasification and conditioning parameters (residence time, temperature, catalysts, etc.) mainly depends on S/B ratio and PSA efficiency. Being the PSA efficiency a technological parameter rather than an operational parameter, only the variation of $S / B$ has been considered in the following sensitivity analysis.

The off-gas use for CHP was considered within the system boundaries together with the consequently avoided conventional electricity production, while heat generation has been disregarded. Indeed, electricity can be used for own demand and injected to the grid, meanwhile the heat produced by CHP can only be used if there is a near low temperature heat demand. In accordance to ISO standards, allocation procedure is avoided by system expansion in this LCA study.

During biomass-based hydrogen production, hydrogen and off-gas are coproduced. The hydrogen was considered as the main product, although the produced electricity from off-gas can be sold to the national grid. In fact, it is considered as an avoided input in the base case of this study. In other words, the system is expanded rather than allocated. Therefore, hydrogen production was only addressed as the base case. In addition, impacts derived from the production and transmission of the avoided electricity were also included within the subsystem boundaries in this case.

\section{Results}

Table 7 summarizes the LCA characterization results for the different subsystems under study per functional unit. Positive values are environmental burdens while negative values signify environmental credits or benefits accrued from carbon dioxide uptake and the substitution of electricity from national grid.

Table 7. Characterization results corresponding to the production of $1 \mathrm{MJ}_{\mathrm{H} 2}$.

\begin{tabular}{ccccccc}
\hline Category & Unit & Total & SS1 & SS2 & SS3 & SS4 \\
\hline GWP & $\mathrm{Kg} \mathrm{CO}_{2}$ eq & 0.042 & -0.12 & 0.19 & 0.11 & -0.14 \\
$\mathrm{EP}$ & $\mathrm{Kg} \mathrm{PO}_{4}$ eq & $2.6 \times 10^{-4}$ & $5 \times 10^{-4}$ & $3.6 \times 10^{-5}$ & $3.3 \times 10^{-6}$ & $-2.8 \times 10^{-4}$ \\
$\mathrm{AP}$ & $\mathrm{Kg} \mathrm{SO}_{2}$ eq & $-4.5 \times 10^{-4}$ & $2 \times 10^{-4}$ & $1.3 \times 10^{-4}$ & $1.5 \times 10^{-5}$ & $-8 \times 10^{-4}$ \\
$\mathrm{POFP}$ & $\mathrm{Kg} \mathrm{C}_{2} \mathrm{H}_{4}$ eq & $-1.8 \times 10^{-5}$ & $6 \times 10^{-6}$ & $2.7 \times 10^{-6}$ & $3.3 \times 10^{-6}$ & $-3 \times 10^{-5}$ \\
$\mathrm{CED}$ & $\mathrm{MJ} \mathrm{eq}$ & -0.46 & 0.39 & 0.14 & 0.3 & -1.3 \\
\hline
\end{tabular}

Figure 4 displays the relative contributions of each subsystem to the environmental results for the studied system. According to these results, the biomass production (SS1) shows high influence over the environmental profile, especially in term of EP with a contribution of $60 \%$. This result is mainly related to the emissions derived from fertilizer application. In addition, the large amount of energy required to produce fertilizer causes intense fossil energy consumption in feedstock production phase. Contrarily, this subsystem achieves a positive effect on GWP owing to the $\mathrm{CO}_{2}$ uptake by photosynthesis. Therefore, the emission of $120 \mathrm{~g} \mathrm{CO}_{2}$ eq per functional unit is avoided. The main environmental impacts of the syngas production (SS2) are observed on GWP (34\%) and AP (15\%), 
mostly related with flue gas emitted from gasifier combustor and feedstock supply. The syngas conversion (SS3) has relatively lower impact on GWP (19\%) than the other categories.

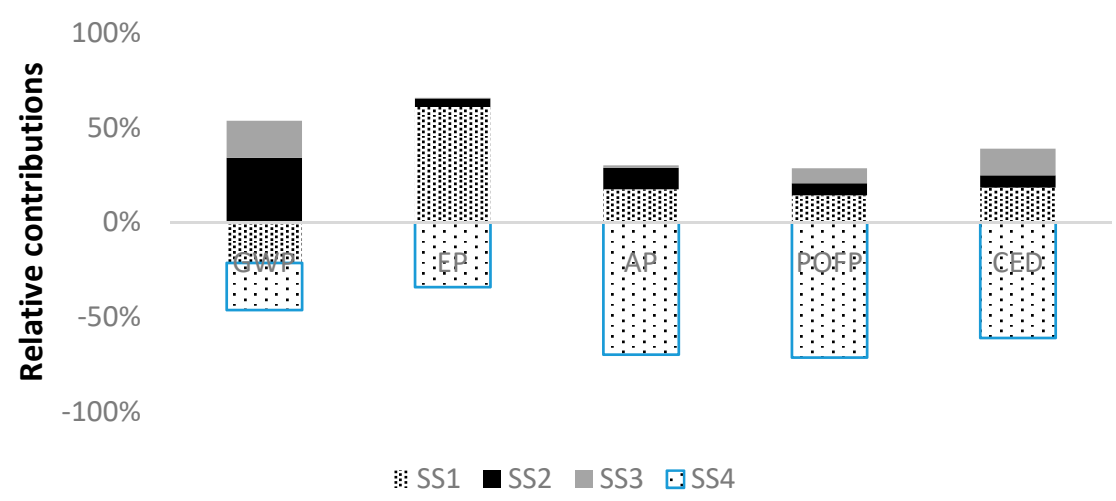

Figure 4. Relative contributions from subsystems involved to each impact category.

SS4 covers the energy generation from off-gas and its utilization as electricity. Thus, the production of electricity from the grid is avoided. As shown in Table 7, it leads to environmental benefits in terms of all the analyzed categories. In the following, a detailed assessment per subsystem has been carried out to recognize in detail the main contribution to these environmental outcomes.

As displayed in Figure 5, impact of fertilizers in SS1 is notable in EP, AP and POCP categories with a contribution greater than $84 \%$ because of drastic energy consumption in production of nitrogen fertilizer required. Irrigating orchard, owing to diesel and electricity requirements in irrigation, has also impact on AP and POFP with 5\% and 15\%, respectively. Regarding GWP, the fixation $\mathrm{CO}_{2}$ by photosynthesis can offset the GHG emitted throughout the cultivation system which are chiefly derived from fertilizer production.

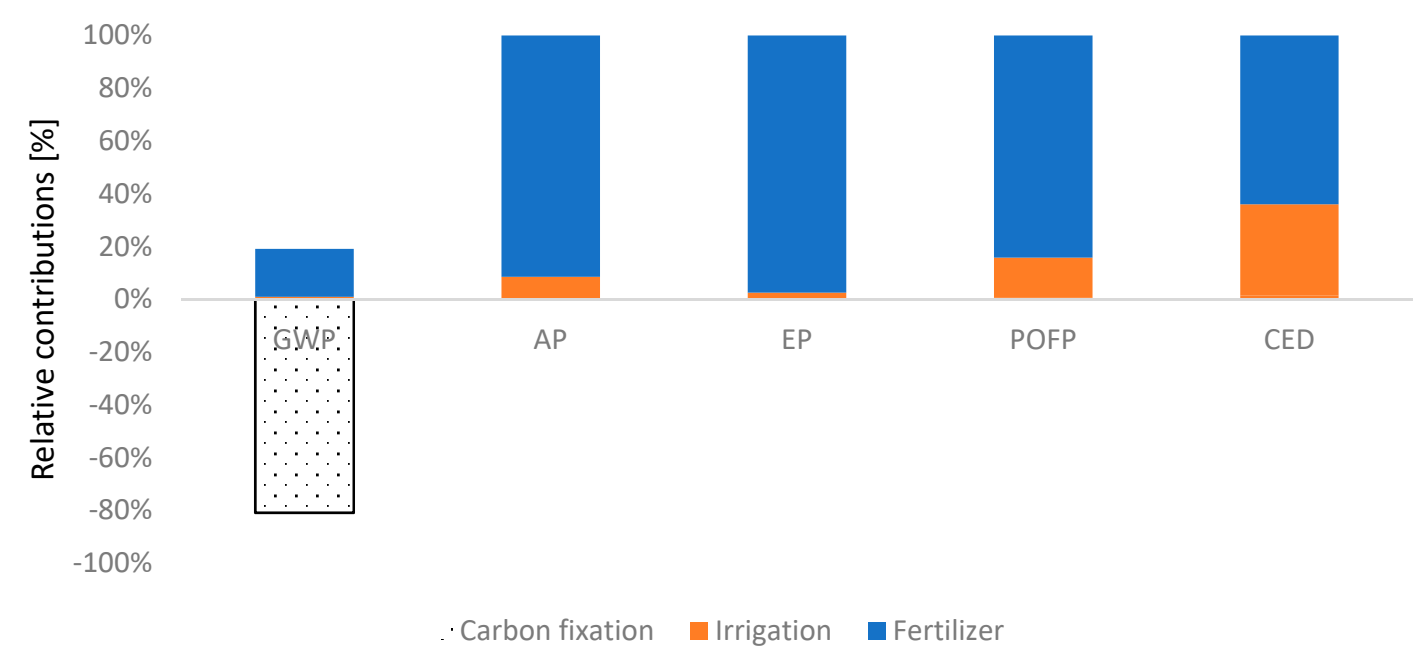

Figure 5. Breakdown of contributions from process involved in Subsystem 1.

With regard to the syngas production process (SS2), flue gas emission from gasifier burner has the largest proportion of total GWP (55\%). By virtue of carbon fixation of feedstock, this impact eventually experiences a massive decrease.

The other categories (AP, POFP and EP) are significantly influenced by feedstock supply process. Moreover, the electricity required to run the gasification has been taken from the Italian grid; its production turns out as second large contributor for AP and POFP categories with $16 \%$ and 23\%, 
respectively. Eighty percent of the electricity consumption in SS2 is due to the air blower to provide air needed for gasification process.

In SS3, the syngas production phase impacts on all the environmental categories. In particular, for EP, it impacts with $97 \%$ related to feedstock and fertilizer consumption. The materials used for syngas conversion to hydrogen have minor impact on this subsystem. Among them, the $\mathrm{Cu}$ foam production has higher environmental impact than the other materials accounting for almost the $3.6 \%$ of the impact on AP and POFP.

In SS4, the emissions from the $\mathrm{CHP}\left(\mathrm{SO}_{2}\right.$ and $\left.\mathrm{NO}_{\mathrm{x}}\right)$ have been estimated according to emission limits legislated by European Commission. Carbon dioxide released by off-gas burning is biogenic and it is not treated as a net source of carbon dioxide by IPCC. The detailed information is indicated in Table 8. The avoided emissions from electricity production and transmission, as shown in Figure 6, have the greatest negative impact on all categories.

Table 8. Global inventory data (per $1 \mathrm{MJ}_{\mathrm{H} 2}$ ) for Subsystem 4.

\begin{tabular}{|c|c|c|c|}
\hline \multicolumn{2}{|c|}{ Input from Technosphere } & \multicolumn{2}{|c|}{ Output to Technosphere } \\
\hline \multicolumn{2}{|c|}{ Materials and fuels } & \multicolumn{2}{|c|}{ Avoided products } \\
\hline \multirow[t]{3}{*}{ Off-gas (from SS3) } & $1.33 \mathrm{MJ}$ & Electricity & $0.26 \mathrm{kWh}$ \\
\hline & & \multicolumn{2}{|c|}{$\begin{array}{l}\text { Output to environment } \\
\text { Emissions to air }\end{array}$} \\
\hline & & Sulfur dioxide & $2 \times 10^{-6} \mathrm{~kg}$ \\
\hline
\end{tabular}

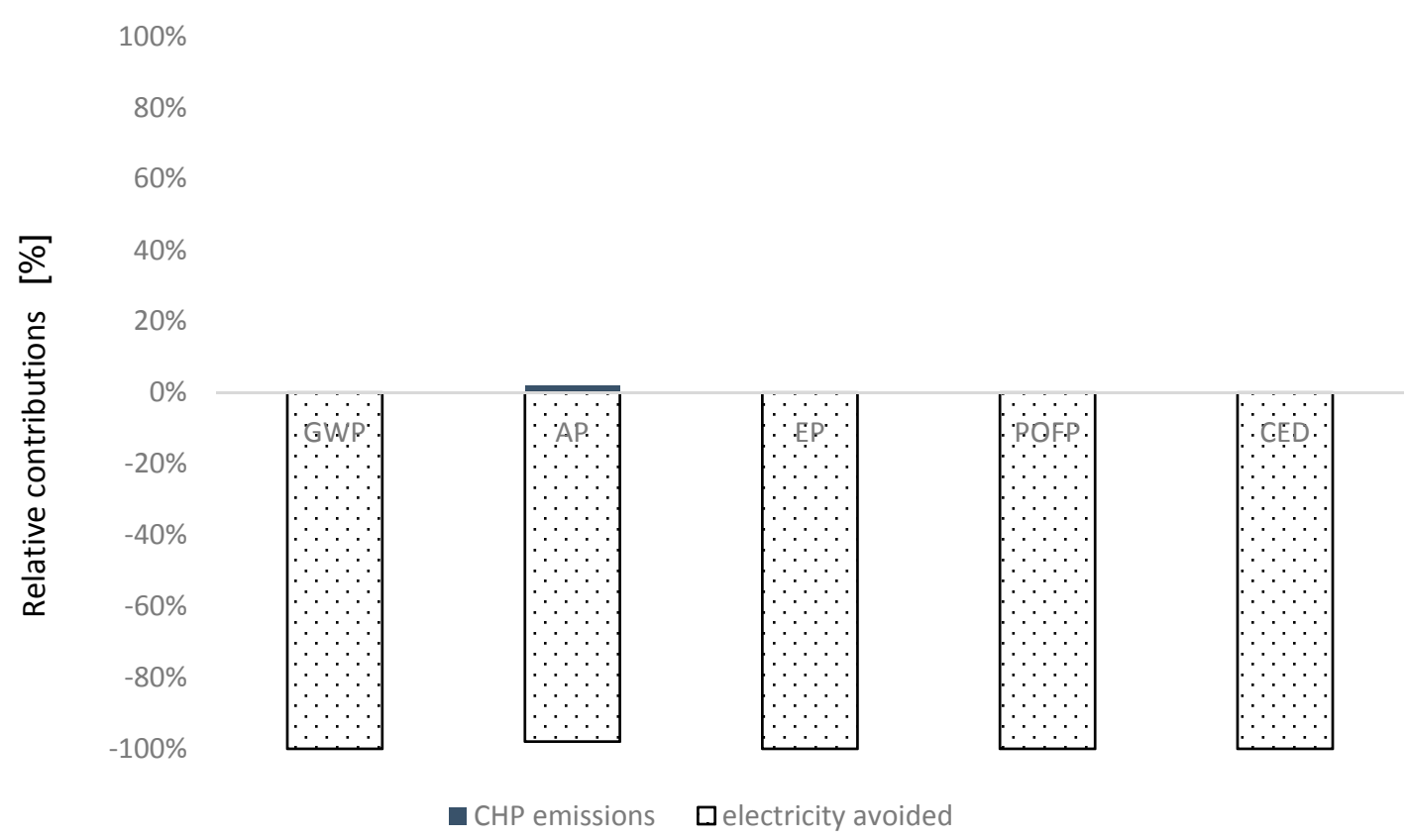

Figure 6. Breakdown of contributions from process involved in Subsystem 4.

The renewability score of hydrogen under the conditions considered in our study has been fixed at $90 \%$, which is close to the values defined for wind and solar based hydrogen production, $96 \%$ and $93 \%$, respectively [51]. In fact, high energy saving in SS4 leads to achieving this appreciative value.

To calculate the renewability score in the current study, the energy content of biomass as the renewable energy was considered $18 \mathrm{MJ} / \mathrm{kg}$ biomass [46]. Therefore, the consumption of $0.144 \mathrm{~kg}$ biomass per $1 \mathrm{MJ}_{\mathrm{H} 2}$ equals to $2.6 \mathrm{MJ}$ biomass-renewable energy consumption. According to the cumulative energy demand indicator (Table 7), $0.46 \mathrm{MJ}$ energy per $1 \mathrm{MJ}_{\mathrm{H} 2}$ would be saved in the 
whole life cycle. In fact, the electricity produced from off-gas leads to $1.3 \mathrm{MJ}$ energy saving per 1 $\mathrm{MJ}_{\mathrm{H} 2}$. The non-renewable energy of whole life cycle has been calculated as $0.22 \mathrm{MJ} / \mathrm{MJ}_{\mathrm{H} 2}$ considering $43 \%$ contribution of off-gas treatment subsystem (SS4) to save energy. On the other hand, if SS4 were excluded from the model, the $\mathrm{H}_{2}$ renewability could be expressed as $75 \%$. In other words, off gas treatment can improve hydrogen renewability by $15 \%$. According to [6] and Table A1 in Appendix A, other approaches for hydrogen production are compared in Figure 7.

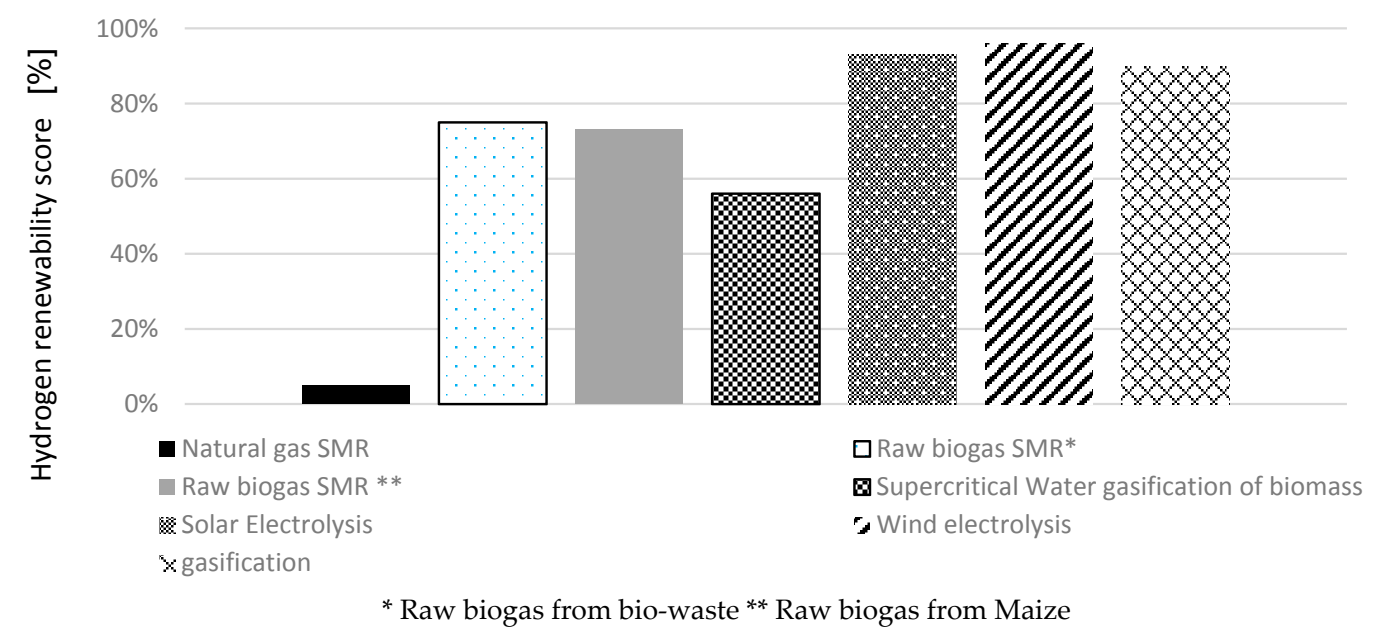

Figure 7. Hydrogen renewability for each technology [6].

\section{Discussion}

In this section, the results obtained in our study for the GWP, AP and EP impact categories are compared with other LCA studies. To simplify these comparisons, our results are presented using the same functional units as other studies $\left(0.042 \mathrm{~kg} \mathrm{CO}_{2}\right.$ eq per $\mathrm{MJ}_{\mathrm{H} 2}, 0.45 \mathrm{~kg} \mathrm{CO}_{2}$ eq per $\mathrm{Nm}^{3} \mathrm{H} 2$ or $15.96 \mathrm{CO}_{2}$ eq g/s).

Kalinci et al. [9] reported values of GWP as $17.13 \mathrm{CO}_{2}$ eq g/s in the CFBG system and $0.175 \mathrm{CO}_{2}$ eq $\mathrm{g} / \mathrm{s}$ in the DG system. In this study, the production of pine wood as feedstock for $\mathrm{H}_{2}$ production in Proton Exchange Membrane (PEM) fuel cell vehicle were defined into system boundary. $\mathrm{H}_{2}$ compression and transportation have been found as the main sources of environmental impact. Although the authors consider more subsystems and a wider system boundary, their result for the CFBG (comparable with our system) is just marginally higher than the one of our system. This is justified by the kind of biomass used, which does not need cultivation process and has a greater carbon fixation.

Moreno and Dufour [21] reported values for the GWP concerning different biomasses. Economic allocation has been considered to designate relevant emissions to waste biomass in orchard products. They found that use of allocation approach leads to decrease in $\mathrm{CO}_{2}$ fixation and carbon credits of waste, since it is distributed between fruit with $90-99 \%$ of total price and waste. Therefore, the GWP, for almond pruning, by considering or not the allocation has been determined as 1.5 and $0.18 \mathrm{~kg} \mathrm{CO}$ eq per $\mathrm{Nm}^{3}$ of hydrogen, respectively and GWP for vine pruning by considering or not the allocation 1.1 and $0.2 \mathrm{~kg} \mathrm{CO}_{2}$ eq per $\mathrm{Nm}^{3}$ of hydrogen, respectively. In this estimation, non-converted $\mathrm{CH}_{4}$ has been recovered into system to provide energy needs. The emissions estimated in this study are slightly lower than the ones in our study due to the use different type of gasifier. In fact, in line with results obtained by [9], fixed bed gasifier released lower emission than fluidized bed gasifier.

Thus, differences on the feedstock and the system boundaries have influence on the results and explain the variations in relation with other studies.

In other research [52], the $\mathrm{CO}_{2}$ emitted from raw biogas reforming under two different feedstocks (maize and bio waste) was assessed. The GWP value is estimated to be $0.046 \mathrm{~kg} \mathrm{CO}_{2}$ eq. per $1 \mathrm{MJ}_{\mathrm{h} 2}$ 
for maize-based biogas and $0.037 \mathrm{~kg} \mathrm{CO}$ eq. if bio waste is used as feedstock. The emissions from fertilizer supply and use of diesel for farming machines in maize cultivation are mainly responsible for these values. These results are quite similar to the system investigated in this study. However, the value reported to generate $\mathrm{H}_{2}$ by natural gas $\mathrm{SMR}$ was $0.1 \mathrm{~kg} \mathrm{CO}_{2}$ per $1 \mathrm{MJ}_{\mathrm{H} 2}[6,53,54]$. Therefore, $0.058 \mathrm{~kg} \mathrm{CO}_{2}$ per $1 \mathrm{MJ}_{\mathrm{H} 2}$ can be reduced if waste biomass gasification is utilized to produce hydrogen.

Regarding the other impact categories, remarkable differences have been identified. In terms of $\mathrm{AP}$ and EP, Moreno and Dufour [21] reported $0.006 \mathrm{~kg} \mathrm{SO}_{2}$ eq and $0.008 \mathrm{~kg} \mathrm{SO}_{2}$ eq and $0.03 \mathrm{~kg} \mathrm{PO}_{4}$ and $0.045 \mathrm{~kg} \mathrm{PO}_{4}$ eq per $\mathrm{Nm}^{3}$ of hydrogen for vine and almond pruning, respectively. According to these authors, these categories were significantly affected by the emissions of nitrate and ammonia used as fertilizer.

Thus, Table 9 summarizes the differences with the reviewed studies.

Table 9. Comparative synoptic of this and previous researches.

\begin{tabular}{|c|c|c|c|c|c|}
\hline GWP & AP & EP & \multirow{2}{*}{ Feedstock } & \multirow{2}{*}{$\begin{array}{c}\text { Handling } \\
\text { Multifunctional } \\
\text { Process } \\
\end{array}$} & \multirow{2}{*}{ Reference } \\
\hline $\mathrm{kg} \mathrm{CO}{ }_{2} / \mathrm{Nm}^{3}{ }_{\mathrm{H} 2}$ & $\mathrm{~kg} \mathrm{SO}_{2} / \mathrm{Nm}^{3}{ }_{\mathrm{H} 2}$ & $\mathrm{~kg} \mathrm{PO}_{4} / \mathrm{Nm}^{3}{ }_{\mathrm{H} 2}$ & & & \\
\hline 0.45 & -0.0048 & 0.0028 & Almond shell & System expansion & Our result \\
\hline 1.5 & 0.0009 & 0.0054 & Almond pruning & Economic allocation & [21] \\
\hline 0.18 & 0.008 & 0.045 & Almond pruning & - & [21] \\
\hline 1.1 & 0.001 & 0.005 & Vine pruning & Economic allocation & [21] \\
\hline 0.2 & 0.006 & 0.03 & Vine pruning & - & [21] \\
\hline $\mathrm{kg} \mathrm{CO}_{2} / \mathrm{MJ}_{\mathrm{H} 2}$ & $\mathrm{~kg} \mathrm{SO}_{2} / \mathrm{MJ}_{\mathrm{H} 2}$ & $\mathrm{~kg} \mathrm{PO}_{4} / \mathrm{MJ}_{\mathrm{H} 2}$ & & & \\
\hline 0.042 & $-4.5 \times 10^{-4}$ & $2.6 \times 10^{-4}$ & Almond shell & System expansion & Our result \\
\hline 0.046 & - & - & Maize-biogas & - & [52] \\
\hline 0.037 & - & - & waste-biogas & - & [52] \\
\hline 0.1 & - & - & Methane & - & {$[6,53,54]$} \\
\hline $\mathrm{g} \mathrm{CO}_{2} / \mathrm{s}$ & - & - & & & \\
\hline 15.96 & - & - & Almond shell & System expansion & Our result \\
\hline 17.13 & - & - & Pine wood & - & [9] \\
\hline
\end{tabular}

\section{Sensitivity Analysis}

Sensitivity analysis has been performed to assess influence of $\mathrm{H}_{2}$ productivity and the allocation method used in the model. As mentioned in Section 2, among several factors affecting $\mathrm{H}_{2}$ productivity, the steam to biomass ratio (S/B), (see Section 3.4) has been chosen to assess hydrogen production. In Figure 8, the current status characterizes the gasification system presented in Section $3(\mathrm{~S} / \mathrm{B}=0.5)$. This status has been compared with the LCA output considering the S/B ratio equal to 1 and 1.5 (Table 10). Therefore, the results of this study have been compared with results related to S/B 1 and 1.5. The experimental conditions for these different ratios are found in [38].

Table 10. Syngas composition in outlet of gasifier and inlet of WGS.

\begin{tabular}{ccccc}
\hline \multirow{2}{*}{ Composition (Unit) } & \multicolumn{2}{c}{ Outlet Gasifier } & \multicolumn{3}{c}{ Outlet WGS } \\
\cline { 2 - 5 } & S/B 1 & S/B 1.5 & S/B 1 & S/B 1.5 \\
\hline Gas yield & 1.63 & 1.72 & 1.9 & 2 \\
$\left(\mathrm{Nm}^{3}{ }_{\text {dry }} / \mathrm{kg}_{\text {bio,daf }}\right)$ & 49 & 51 & 58 & 60 \\
$\mathrm{H}_{2}\left(\%_{\text {dry }}\right)$ & 7 & 6 & 7 & 5 \\
$\mathrm{CH}_{4}(\%$ dry & 24 & 23 & 3 & 2 \\
$\mathrm{CO}\left(\%_{\text {dry }}\right)$ & 20 & 46 & 32 & 33 \\
$\mathrm{CO}_{2}\left(\%_{\text {dry }}\right)$ & 34 & 6.97 & 40 & 50 \\
$\mathrm{H}_{2} \mathrm{O}\left(\%_{\text {wet }}\right)$ & 5.51 & 1.53 & 4.7 & 6 \\
$\mathrm{C}_{6} \mathrm{H}_{6}\left(\mathrm{~g} / \mathrm{Nm}_{\text {dry }}^{3}\right)$ & 1.23 & 0.77 & 1.05 & 1.3 \\
$\mathrm{C}_{7} \mathrm{H}_{8}\left(\mathrm{~g} / \mathrm{Nm}^{3}\right.$ dry & 0.33 & 0.29 & 0.66 \\
$\mathrm{C}_{10} \mathrm{H}_{8}\left(\mathrm{~g} / \mathrm{Nm}_{\text {dry }}^{3}\right)$ & & &
\end{tabular}




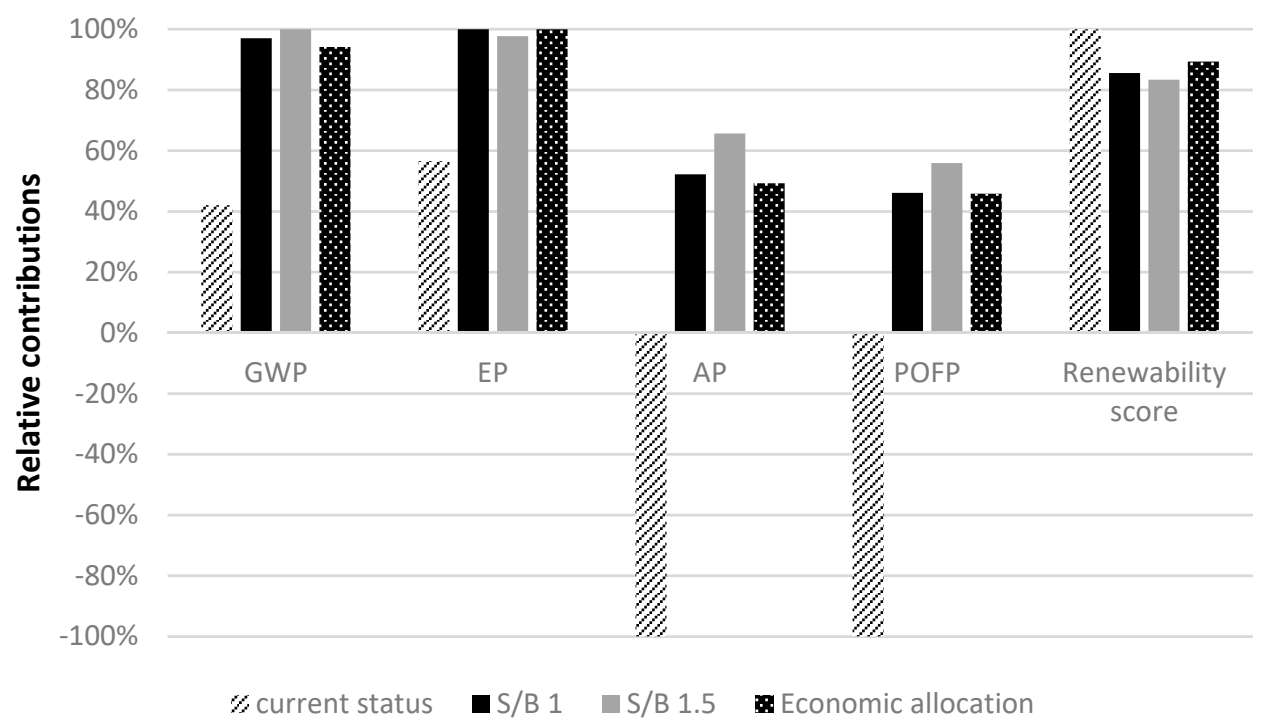

Figure 8. Sensitive analysis results for increase in hydrogen production.

According to Table 10, increasing the steam to biomass ration improves gas yield and $\mathrm{H}_{2}$ production but also the $\mathrm{CO}_{2}$ and $\mathrm{H}_{2} \mathrm{O}$ content. The gas yield and $\mathrm{H}_{2}$ production increase is more relevant than the increase of inert gas, because the LHV of the syngas increases [36].

Figure 8 shows that, in cases of S/B 1 and 1.5, impacts are higher (from 60\% of GWP to around $100 \%$ for AP and POFP). Numerical values related to Figure 8 are presented in Table 11. This is due to the decrease in electricity production and subsequently decrease in environmental benefits (see Section 4). In addition, regarding renewability score, the case of S/B 0.5 shows the best performance. The economic allocation case, where environmental impacts are allocated to $\mathrm{H}_{2}$ and electricity, shows environmental improvements compared with the case of S/B 1 and 1.5 but always higher than the case of S/B 0.5. This means that increase in hydrogen production not necessarily results in diminution of environmental impacts on the contrary these impacts can grow. Rise in hydrogen produced leads to fall in off-gas volume, electricity obtained and its avoided impacts. These results clarify role importance of by-products in environmental efficiency of hydrogen production. In addition, as the Italian electric profile includes high fraction of non-renewable sources in [27], which results that more than $65 \%$ is generated from non-renewable sources, mainly natural gas, oil and hard coal, renewability of hydrogen can be affected by decline in avoided grid derived electricity demand, which entails consumption of fossil-based electricity due to drop in off-gas volume.

Table 11. Comparison of different scenarios.

\begin{tabular}{cccccc}
\hline \multirow{2}{*}{ Impact Category } & \multirow{2}{*}{ Unit } & \multicolumn{3}{c}{ Scenarios } \\
\cline { 3 - 6 } & & Current Status & S/B 1 & S/B 1.5 & Economic Allocation \\
\hline GWP & $\mathrm{Kg} \mathrm{CO}_{2}$ eq & 0.042 & 0.097 & 0.1 & 0.094 \\
EP & $\mathrm{Kg} \mathrm{PO}_{4}$ eq & $2.6 \times 10^{-4}$ & $4.6 \times 10^{-4}$ & $4.4 \times 10^{-4}$ & $4.5 \times 10^{-4}$ \\
$\mathrm{AP}$ & $\mathrm{Kg} \mathrm{SO}_{2}$ eq & $-4.5 \times 10^{-4}$ & $2.3 \times 10^{-4}$ & $2.9 \times 10^{-4}$ & $2.2 \times 10^{-4}$ \\
POFP & $\mathrm{Kg} \mathrm{C}_{2} \mathrm{H}_{4}$ eq & $-1.8 \times 10^{-5}$ & $8.3 \times 10^{-6}$ & $1 \times 10^{-5}$ & $8.2 \times 10^{-6}$ \\
Renewability score & $\%$ & 90 & 77 & 75 & 80 \\
\hline
\end{tabular}

Decentralized power plants entail environmental benefits despite the technical and economic challenges for this scale of power plant. Indeed, investment cost per power unit of small scale power plants is higher than large scale plants and there are higher requirements for the technological development of these small-scale power plants (thermal balance, etc.). Moreover, hydrogen production cost can be higher (10 euro $/ \mathrm{kg}$ ) compared with large scale production cost (1-2 euro $/ \mathrm{kg})$. 
On the other hand, the energy, economic and environmental impacts of the biomass transportation are relatively lower due to avoiding distribution and because CHP and CCHP systems can also be more applicable for small scale power plants as heating and cooling production is more effortlessly distributed and usable. In fact, currently, hydrogen production systems at large scale can be more technically and economically applicable, but they impose higher impacts.

\section{Conclusions}

This study evaluates the environmental characteristics of hydrogen and electricity production in an innovative small-scale biomass gasification plant. The LCA methodology has been applied to assess the environmental performance of this production scenario.

Real input and output flows for the whole system have been identified and managed in detail from a cradle-to-gate perspective. This study showed that the biomass production phase influences all impact categories, which is a unanimous result of previous research. Furthermore, due to multifunctional nature of this process and considering byproduct converted into electricity as well as no auxiliary energy consumption, these environmental impacts massively decrease. Negative values in AP, POFP and CED illustrate this improvement. Following this result, a sensitivity analysis was conducted to assess the influence of the variations in hydrogen and byproduct volume on environmental impacts. The $\mathrm{S} / \mathrm{B}$ ratio has been chosen as parameter affecting both off-gas and hydrogen production because it is commonly recognized as the main factor in the analysis of performance of gasification process. Results indicate that, although increase in hydrogen production can directly reduce all environmental impacts, this implies a fall in off-gas volume, which indirectly leads to increased impacts for all categories. As a result, in the considered production system, the environmental effects cannot be univocally represented by hydrogen production rate because relevance of byproducts produced plays an even more important role. In this line of research, development of system boundary into bio-refinery products can also lead to higher reduction in environmental footprints of hydrogen production system. In addition, the sensitivity analysis shows that allocation method also highly affects the system profile. Allocation of environmental charges can considerably overestimate results. Results of this work have a relevant impact with respect to previous literature works regarding hydrogen production by means of biomass gasification because it has analyzed the effect of some design parameters on the environmental impact of the overall system, quantifying the contribution, for each category, of the different configurations.

Finally, despite the limits of small scale hydrogen production system, many potential advantages of this category can be enumerated. Therefore, a highly efficient small-scale power plant with low environmental burden needs to be developed to tackle the low energy density and perishability of biomass.

Acknowledgments: This research has been supported by the following projects: the Italian national Ricerca di Sistema research project HBF2.0 funded by Italian Ministry for Economic Developments and European project UNIfHY (UNIque gasifier for HYdrogen production) funded by FP7 European Commission Programme. This research has been supported by the following projects: HBF2.0 funded by Italian Ministry of Economic Development within the Italian National System Research, in the Programme called Ricerca di Sistema, and the European project UNIfHY (UNIque gasifier for HYdrogen production) funded by FP7 EuropeanCommissionProgramme. Within these projects we thank especially Andrea Di Carlo of University of L'Aquila, for the plant flowsheet and part of the plant data and Donatella Barisano of ENEA for the data and the picture of the UNIFHY $1000 \mathrm{kWth}$ plant.

Author Contributions: Enrico Bocci and Mauro Villarini conceived and designed the model of the plant, took care of the system energy balance and, with Andrea Colantoni, revised the functional unit data and the paper; Sara Rajabi Hamedani and Michele Moretti developed the LCA analysis; Sara Rajabi Hamedani and Andrea Colantoni analyzed the data; contributed reagents/materials/analysis tools; Sara Rajabi Hamedani wrote the paper with Mauro Villarini.

Conflicts of Interest: The authors declare no conflicts of interest. 


\section{Nomenclature}

$\begin{array}{ll}\text { AP } & \text { acidification potential } \\ \text { CED } & \text { Cumulative Energy Demand } \\ \text { CFC } & \text { Catalytic Filter Candles } \\ \text { CHP } & \text { Combined Heat and Power } \\ \text { CCHP } & \text { Combined Cooling Heating and Power } \\ \text { EP } & \text { eutrophication potential } \\ \text { FU } & \text { Functional Unit } \\ \text { GWP } & \text { global warming potential } \\ \text { IBFB } & \text { Bubbling Fluidized Bed gasifier } \\ \text { ICE } & \text { Internal Combustion Engine } \\ \text { LCA } & \text { Life Cycle Assessment } \\ \text { LCI } & \text { Life Cycle Inventory } \\ \text { LHV } & \text { Low Heating Value } \\ \text { POFP } & \text { photochemical oxidation potential } \\ \text { PSA } & \text { Pressure Swing Adsorber } \\ \text { SMR } & \text { Steam Methane Reforming } \\ \text { SS1 } & \text { Subsystem1 } \\ \text { SS2 } & \text { Subsystem2 } \\ \text { SS3 } & \text { Subsystem3 } \\ \text { SS4 } & \text { Subsystem4 } \\ \text { WGS } & \text { Water Gas Shift }\end{array}$

\section{Appendix}

Table A1. Energy demand per $\mathrm{kWh}_{\mathrm{H} 2}$ and $\mathrm{H}_{2}$ renewability score [6].

\begin{tabular}{ccccc}
\hline Scenario & $\begin{array}{c}\text { Fossil Energy } \\
\text { (kWh Primary Energy) }\end{array}$ & $\begin{array}{c}\text { Nuclear Energy } \\
\text { (kWh Primary Energy) }\end{array}$ & $\begin{array}{c}\text { Renewable Energy } \\
\text { (kWh Primary Energy) }\end{array}$ & $\begin{array}{c}\mathbf{H}_{\mathbf{2}} \text { Renewability } \\
\text { Score (\%) }\end{array}$ \\
\hline Natural gas & 2.3 & 0.5 & 0.14 & 5 \\
Wind electrolysis & 0.06 & 0.03 & 2 & 96 \\
SCWG & 1.2 & 0.4 & 2.1 & 3 \\
Raw biogas SMR & 0.6 & 0.4 & 3 & 75 \\
Raw biogas SMR-maize & 0.6 & 0.5 & 3 \\
\hline
\end{tabular}

\section{References}

1. O'Keefe, P.; Geoff, O.; Nicola, P. The Future of Energy Use, 2nd ed.; Routledge: Abingdon, UK, 2010.

2. IIASA. I institude for applied systems analysis. In Energy Perspectives for Eurasia and the Kyoto Protocol; IIASA: Laxenburg, Austria, 1998.

3. Khila, Z.; Baccar, I.; Jemel, I.; Hajjaji, N. Thermo-environmental life cycle assessment of hydrogen production by autothermal reforming of bioethanol. Energy Sustain. Dev. 2017, 37, 66-78. [CrossRef]

4. Ball, M.; Wietschel, M. The future of hydrogen-opportunities and challenges. Int. J. Hydrog. Energy 2009, 34, 615-627. [CrossRef]

5. Dunn, S. Hydrogen futures: Toward a sustainable energy system. Int. J. Hydrog. Energy 2002, 27, $235-264$. [CrossRef]

6. Fuell cells and hydrogen joint undertaking. In Study on Hydrogen from Renewable Resources in the EU, Final Report; FCH: Brussels, Belgium, 2015. [CrossRef]

7. Singh, A.; Sevda, S.; Abu Reesh, I.; Vanbroekhoven, K.; Rathore, D.; Pant, D. Biohydrogen Production from Lignocellulosic Biomass: Technology and Sustainability. Energies 2015, 8, 13062-13080. [CrossRef]

8. Susmozas, A.; Iribarren, D.; Dufour, J. Life-cycle performance of indirect biomass gasification as a green alternative to steam methane reforming for hydrogen production. Int. J. Hydrog. Energy 2013, 38, 9961-9972. [CrossRef] 
9. Kalinci, Y.; Hepbasli, A.; Dincer, I. Life cycle assessment of hydrogen production from biomass gasification systems. Int. J. Hydrog. Energy 2012, 37, 14026-14039. [CrossRef]

10. Bocci, E.; Di Carlo, A.; McPhail, S.J.; Gallucci, K.; Foscolo, P.U.; Moneti, M.; Villarini, M.; Carlini, M. Biomass to fuel cells state of the art: A review of the most innovative technology solutions. Int. J. Hydrog. Energy 2014, 39, 21876-21895. [CrossRef]

11. Koroneos, C.; Dompros, A.; Roumbas, G. Hydrogen production via biomass gasification-A life cycle assessment approach. Chem. Eng. Process. Process Intensif. 2008, 47, 1267-1274. [CrossRef]

12. IEA Bioenergy. Bioenergy - A Sustainable and Reliable Energy Source a Review of Status and Prospects; IEA Bioenergy: Wageningen, The Netherlands, 2009; p. 108.

13. Staples, M.D.; Malina, R.; Olcay, H.; Pearlson, M.N.; Hileman, J.I.; Boies, A.; Barrett, S.R.H. Lifecycle greenhouse gas footprint and minimum selling price of renewable diesel and jet fuel from fermentation and advanced fermentation production technologies. Energy Environ. Sci. 2014, 7, 1545-1554. [CrossRef]

14. ISO 14040. Environmental Management-Life Cycle Assessment-Principles and Framework 2006; ISO: Geneva, Switzerland, 2006.

15. Meul, M.; Van Middelaar, C.E.; de Boer, I.J.M.; Van Passel, S.; Fremaut, D.; Haesaert, G. Potential of life cycle assessment to support environmental decision making at commercial dairy farms. Agric. Syst. 2014, 131, 105-115. [CrossRef]

16. Moretti, M.; De Boni, A.; Roma, R. Economic and environmental sustainability of forestry measures in Apulia Region Rural Development Plan: An application of life cycle approach. Land Use Policy 2014, 41, 284-289. [CrossRef]

17. Murphy, D.; Carbajales-Dale, M.; Moeller, D. Comparing Apples to Apples: Why the Net Energy Analysis Community Needs to Adopt the Life-Cycle Analysis Framework. Energies 2016, 9, 917. [CrossRef]

18. Cherubini, F.; Strømman, A.H. Life cycle assessment of bioenergy systems: State of the art and future challenges. Bioresour. Technol. 2011, 102, 437-451. [CrossRef] [PubMed]

19. Cherubini, F. The biorefinery concept: Using biomass instead of oil for producing energy and chemicals. Energy Convers. Manag. 2010, 51, 1412-1421. [CrossRef]

20. Lelek, L.; Kulczycka, J.; Lewandowska, A.; Zarebska, J. Life cycle assessment of energy generation in Poland. Int. J. Life Cycle Assess. 2015, 21, 1-14. [CrossRef]

21. Moreno, J.; Dufour, J. Life cycle assessment of hydrogen production from biomass gasification. Evaluation of different Spanish feedstocks. Int. J. Hydrog. Energy 2013, 38, 7616-7622. [CrossRef]

22. Suwatthikul, A.; Limprachaya, S.; Kittisupakorn, P.; Mujtaba, I. Simulation of Steam Gasification in a Fluidized Bed Reactor with Energy Self-Sufficient Condition. Energies 2017, 10, 314. [CrossRef]

23. Buchholz, T.; Volk, T.A. Considerations of Project Scale and Sustainability of Modern Bioenergy Systems in Uganda. J. Sustain. For. 2012, 31, 154-173. [CrossRef]

24. Bocci, E.; Sisinni, M.; Moneti, M.; Vecchione, L.; Di Carlo, A.; Villarini, M. State of art of small scale biomass gasification power systems: A review of the different typologies. Energy Procedia 2014, 45, 247-256. [CrossRef]

25. EU. UNIfHY Collaborative Project, Project ID 299732 7FP n.d. Available online: http:/ / www.fch.europa.eu/ project/unique-gasifier-hydrogen-production (accessed on 14 January 2018).

26. ISO 14044. Environmental Management-Life Cycle Assessment-Requirements and Guidelines 2006; ISO: Geneva, Switzerland, 2006.

27. Lijó, L.; González-garcía, S.; Bacenetti, J.; Fiala, M.; Feijoo, G.; Lema, J.M.; Moreira, M.T. Life Cycle Assessment of electricity production in Italy from anaerobic co-digestion of pig slurry and energy crops. Renew. Energy 2014, 68, 625-635. [CrossRef]

28. Intergovernmental Panel on Climate Change (IPCC). Guidelines for National Greenhouse Gas Inventories; IPCC: Geneva, Switzerland, 2006.

29. Marvinney, E.; Kendall, A.; Brodt, S. Life Cycle-Based Assessment of Energy Use and Greenhouse Gas Emissions in Almond Production, Part II Uncertainty Analysis through Sensitivity Analysis and Scenario Testing. Res. Anal. 2015, 19, 1019-1029. [CrossRef]

30. European Union. PE-CONS 42/15 DGE 1 EB/vm; European Union: Brussels, Belgium, 2015; Volume 2015. 
31. Fuell Cell and Hydrogen-Joint Undertaking. Guidance Document for Performing LCAs on Fuel Cells and H2 Technologies; Fuell Cell and Hydrogen-Joint Undertaking: Brussels, Belgium, 2011.

32. Guinée, J.B.; Gorrée, M.; Heijungs, R.; Huppes, G.; Kleijn, R.; de Koning, A.; van Oers, L.; Wegener Sleeswijk, A.; Suh, S.; Udo de Haes, H.A.; et al. Handbook on Life Cycle Assessment. Operational Guide to the ISO Standards. Part III: Scientific Background; Kluwer Academic Publishers: Dordrecht, The Netherlands, 2002.

33. PRé. SimaPro Database Manual Methods 2015. Available online: https://www.pre-sustainability.com/ download/DatabaseManualMethods.pdf (accessed on 14 January 2018).

34. Hischier, R.; Weidema, B.; Althaus, H.J.; Bauer, C.; Doka, G.D.R. Implementation of Life Cycle Impact Assessment Methods, Ecoinvent Report; Swiss: Dubendorf, Switzerland, 2010.

35. Neelis, M.-L.; van der Kooi, H.J.; Geerlings, J.J.C. Exergetic life cycle analysis of hydrogen production and storage systems for automotive applications. Int. J. Hydrogen Energy 2004, 29, 537-545. [CrossRef]

36. Pallozzi, V.; Di Carlo, A.; Bocci, E.; Villarini, M.; Foscolo, P.U.; Carlini, M. Performance evaluation at different process parameters of an innovative prototype of biomass gasification system aimed to hydrogen production. Energy Convers. Manag. 2016, 130, 34-43. [CrossRef]

37. Fremaux, S.; Beheshti, S.-M.; Ghassemi, H.; Shahsavan-Markadeh, R. An experimental study on hydrogen-rich gas production via steam gasification of biomass in a research-scale fluidized bed. Energy Convers. Manag. 2015, 91, 427-432. [CrossRef]

38. Hamedani Rajabi, S.; Bocci, E.; Villarini, M.; Di Carlo, A.; Naso, V. Techno-economic Analysis of Hydrogen Production Using Biomass Gasification-A Small Scale Power Plant Study. Energy Procedia 2016, 101, 806-813.

39. GSE. Prezzi Minimi Grantiti Per l'anno 2015; GSE: Chicago, IL, USA, 2015.

40. Alto Garda Sevizi (AGS). Tariffe Di Riferimento IV Trimestre 2015 Ottobre/Dicembre; AGS: Riva del Garda, Italy, 2015.

41. Moneti, M.; Di Carlo, A.; Enrico, B.; Foscolo, P.U.; Villarini, M.; Carlini, M. Influence of the main gasifier parameters on a real system for hydrogen production from biomass. Int. J. Hydrog. Energy 2016, 41, 11965-11973. [CrossRef]

42. Villarini, M.; Bocci, E.; Di Carlo, A.; Savuto, E.; Pallozzi, V. The case study of an innovative small scale biomass waste gasification heat and power plant contextualized in a farm. Energy Procedia 2015, 82, 335-342. [CrossRef]

43. Bocci, E.; Di Carlo, A.; Vecchione, L.; Villarini, M.; De Falco, M.; Dell'Era, A. Technical-economic analysis of an innovative cogenerative small scale biomass gasification power plant. Lect. Notes Comput. Sci. 2013, 7972, 256-270.

44. Kendall, A.; Marvinney, E.; Brodt, S.; Zhu, W. Life Cycle-Based Assessment of Energy Use and Greenhouse Gas Emissions in Almond Production, Part I Analytical Framework and Baseline Results. J. Ind. Ecol. 2015, 19, 1008-1018. [CrossRef]

45. Kendall, A.; Marvinney, E.; Brodt, W.; Zhu, S.; Yuan, J. Greenhouse Gas and Energy Footprint (Life Cycle Assessment) of California Almond Production; Almond board of California: Modesto, CA, USA, 2012.

46. Nanna, F.; Barisano, D.; Villone, A. Deliverable 2.1 Chemical Characterisation of Feedstock. UNIfHY UNIQUE Gasifier for Hydrogen Production; FCH: Brussels, Belgium, 2013.

47. Savuto, E.; Di Carlo, A.; Bocci, E.; D’Orazio, A.; Villarini, M.; Carlini, M.; Foscolo, P.U. Development of a CFD model for the simulation of tar and methane steam reforming through a ceramic catalytic filter. Int. J. Hydrogen Energy 2015, 40, 7991-8004. [CrossRef]

48. Hofbauer, H.; Rauch, R.; Loeffler, G.; Kaiser, S.; Fercher, E.; Tremmel, H. Six years experience with the FICFB-gasification process. In Proceedings of the 12th European Conference and Technology Exhibition on. Biomass for Energy, Industry and Climate Protection, Amsterdam, The Netherlands, 17-21 June 2002; pp. 982-985.

49. Hofbauer, H.; Knoef, H. Success stories on biomass gasification. In Handbook Biomass Gasification; BTG Biomass Technology: Enschede, The Netherlands, 2005.

50. EU. UNIQUE Cooperative Research Project, Contract N.211517 7FP. 2013-01-18 n.d. Available online: http:/ / cordis.europa.eu/result/rcn/55532_en.html (accessed on 14 January 2018).

51. Dufour, J.; Serrano, D.P.; Gálvez, J.L.; González, A.; Soria, E.; Fierro, J.L.G. Life cycle assessment of alternatives for hydrogen production from renewable and fossil sources. Int. J. Hydrogen Energy 2012, 37, 1173-1183. [CrossRef] 
52. Deutsches Biomasseforschungszentrum (DBFZ). Evaluierung der Verfahren und Technologien für die Bereitstellung von Wasserstoff auf Basis von Biomasse; DBFZ: Leipzig, Germany, 2014.

53. Edwards, R.; Hass, H.; Larivé, J.-F.; Lonza, L.; Mass, H.; Rickeard, D. Well-to-Wheel Analysis of Future Automotive fuels and Powertrains in the European Context, Version 4.a. 2014. Available online: http: / / iet.jrc.ec.europa.eu (accessed on 1 March 2018).

54. FCH JU. Fuel Cells and Hydrogen Joint Undertaking (FCH JU), Annual Implamantaion Plant; FCH JU: Bruxelles, Belgium, 2011.

2018 by the authors. Licensee MDPI, Basel, Switzerland. This article is an open access article distributed under the terms and conditions of the Creative Commons Attribution (CC BY) license (http:/ / creativecommons.org/licenses/by/4.0/). 